\title{
Why Women Protest: Insights from Ukraine's EuroMaidan
}

\author{
Olena Nikolayenko and Maria DeCasper
}

Women played a pivotal role in the anti-government protests held in Ukraine from November 2013 to February 2014. Dubbed as the EuroMaidan or the Revolution of Dignity, these protests were initially triggered by President Viktor Yanukovych's abrupt refusal to sign a free trade agreement with the European Union (EU), but rapidly grew into a protest campaign encompassing a wide range of political demands and attracting a cross-cutting coalition of citizens with a shared distaste for the current regime. ${ }^{1}$ In line with Jack Goldstone's definition of a revolution, the EuroMaidan signified "the forcible overthrow of a government through mass mobilization in the name of social justice, to create new political institutions."2 According to some estimates, women constituted nearly half of the participants in these protests marked by "the rapid concentration of protestors in urban spaces and the articulation of demands for political and civil freedoms." ${ }^{3}$ Citizens brushed off the

We thank Harriet Murav, Dmitry Tartakovsky, and the anonymous reviewers for their enormously helpful comments. We are also grateful to participants in the annual meeting of the American Political Science Association, the National Conference on Undergraduate Research, and the Gender and Transformation in Europe Workshop at the Center for European and Mediterranean Studies, New York University for their valuable feedback, as well as to Iryna Bekeshkina, Director of the Ilko Kucheriv Democratic Initiatives Foundation, for generously providing access to the survey data. In addition, Nikolayenko gratefully acknowledges support of this research by the Davis Center for Russian and Eurasian Studies at Harvard University (Visiting Scholars Program) and the Office of Research at Fordham University (2016-17 Faculty Fellowship).

1. Scholars distinguish three phases of the 2013-2014 protest campaign: Student Maidan (November 21-30, 2013), with a high rate of student participation in protest events; Maidan Tabir (December 1, 2013-January 15, 2014) marked by the construction of barricades and the growth of the encampment on the Maidan; and Maidan Sich (January 16, 2014-February 22, 2014), signifying an escalation in police violence and the radicalization of protest tactics. For details, see Yuriy Shveda and Joung Ho Park, "Ukraine's Revolution of Dignity: The Dynamics of Euromaidan.” Journal of Eurasian Studies 7, no. 1 (January 2016): 85-91.

2. Jack A. Goldstone, Revolutions: A Very Short Introduction (Oxford, 2014), 4.

3. The Ilko Kucheriv Democratic Initiatives Foundation (DIF) and the Kyiv International Institute of Sociology (KIIS) conducted a survey of protesters on the Maidan on December 7-8, $2013(n=1,037)$, December 20, $2013(n=515)$, and February 3, $2014(n=502)$. Their findings indicate that the share of female protesters dropped from 42.8 percent in early December 2013 to 11.8 percent in February 2014. See "Vid Maidanu-taboru do Maidanu-sichi: Shcho zminylosia?," at http://kiis.com.ua/?lang=ukr\&cat=reports\&id=226\&page=2 (last accessed March 1, 2018). However, many women claimed their continuous engagement in the protest campaign despite an escalation in police violence and men's attempts to turn them away from the barricades. On this point, see, for example, Tamara Martsenyuk, "Genderna sotsiologiia Maidanu: Rol zhinok u protestakh" (Electronic Archive of the National University of Kyiv-Mohyla Academy, 2014), at http://ekmair.ukma.edu.ua/handle/123456789/3511 (last accessed March 1, 2018); Women of Maidan. Directed by Olha Onyshko and Petro Didula. Kyiv: OliaFilm, 2016; Daria Popova, “Seksizm na Maidani," Spilne: Journal of Social Critique 9 (2015): 78-82, at https://commons.com.ua/uk/seksizm-na-majdani/ (last accessed February 4, 2017). On the definition of the urban civic revolution, see Mark Beissinger, "The Semblance of Democratic Revolution: Coalitions in Ukraine's Orange Revolution," American Political Science Review 107, no. 3 (August 2013): 574-92, 574. 
threat of police violence and stoically braved sub-freezing temperatures to sustain contentious collective action on the Maidan, Kyiv's central square. ${ }^{4}$ Women coordinated the provision of medical supplies, compiled lists of missing persons, offered legal assistance for detained protesters, organized public lectures and documentary screenings inside the encampment, patrolled the barricades, distributed food, and provided first aid as bullets whistled past. Why did women participate in the protest campaign?

Based upon in-depth interviews with female participants in the EuroMaidan, this study uncovers a wide range of motivations for women's engagement in the protest campaign, including dissatisfaction with the government, solidarity with protesters, motherhood, civic duty, and professional service. The majority of the interviewees brought up various political and socioeconomic grievances as a reason for protesting. Apparently, the main demands of the protest campaign-the signing of a free trade agreement with the $\mathrm{EU}$, the resignation of the incumbent government, the implementation of democratic reforms, and the eradication of corruption-resonated with women and influenced their decision to join it. Another significant motivation for women's involvement in the protest activity was solidarity with the protesters, especially spouses and friends. Moreover, women who were themselves mothers drew on the notions of motherhood and mothering to provide a rationale for protesting. Concern over gender equality, however, was rarely cited as a pivotal factor for women's initial involvement in the EuroMaidan. ${ }^{5}$

This study makes an empirical contribution to comparative democratization literature by analyzing motivations for women's engagement in a protest campaign in a repressive political regime. Voluminous research has examined women's political representation and participation in legislative politics in the post-communist region. ${ }^{6}$ Another prolific body of literature has focused

4. The term "EuroMaidan" is a combination of the words Europe and Maidan. The word "maidan" (borrowed from the Ottoman Turkish language) means "a public square" in Ukrainian. In this article we use the Maidan as shorthand for Maidan Nezalezhnosti (Independence Square), an open public space in the center of Kyiv. The city square has served as a center stage for major protest campaigns in post-communist Ukraine, including the Ukraine without Kuchma Movement of 2000-2001, the Orange Revolution of 2004, and the EuroMaidan of 2013-14. For details, see Roman Cybriwsky, "Kyiv's Maidan: From Duma Square to Sacred Space,” Eurasian Geography and Economics 55, no. 3 (2014): $270-85$.

5. It is noteworthy that some women began to demand gender equality in the course of the EuroMaidan. See, for example, Halyna Herasym, "Evromaidan: Chy kukhnia dosi iedyne mistse dlia ukrainskikh zhinok?” Tovaryshka December 23, 2013, at http://tovaryshka.info/euromaidan-kueche/ (last accessed February 4, 2017); Povaha, "Navishcho Ukraini zhninocha sotnia?” April 9, 2014, at http://povaha.org.ua/navischo-ukrajinizhinocha-sotnya/ (last accessed February 4, 2017); Marian J. Rubchak, "A Fiery Maidan Ignites a Feminist Voice,” Perspectives on Europe 44, no. 2 (January 2014): 82-87.

6. See, for example, Yvonne Galligan and Sara Clavero, "Prospects for Women's Legislative Representation in Postsocialist Europe: The Views of Female Politicians," Gender and Society 22, no. 2 (April 2008): 149-71; Grigorii Golosov, "Political Parties, Electoral Systems and Women's Representation in the Regional Legislative Assemblies of Russia, 1995-1998,” Party Politics 7, no. 1 (2001): 45-68; Anna Gwiazda, “Women’s Representation and Gender Quotas: The Case of the Polish Parliament," Democratization 22, no. 4 (2015): 679-97; Ol'ga Gyárfášová, Zora Bútorová, and Jarmila Filadelfiová, "Women and Men in Public Life and Politics," in Monika Bosá, Zora Bútorová, Jarmila Filadelfiová, Ol'ga 
on women's non-governmental organizations and their interactions with the international community. ${ }^{7}$ Engagement in contentious politics constitutes another important mode of women's political participation. ${ }^{8}$ The present study contributes to this growing strand of research.

Gyárfášová, Milan Minarovič, Martina Sekulová, Sylvia Šumšalová, and Marián Velšic, eds., She and He in Slovakia. Gender and Age in the Period of Transition (Bratislava, 2008), 239-58; John Ishiyama, "Women's Parties in Post-Communist Politics," East European Politics and Societies 17, no. 2 (Spring 2003): 266-304; Vlasta Jalušič, "Women in PostSocialist Slovenia: Socially Adopted, Politically Marginalized," in Sabrina Ramet, ed., Gender Politics in the Western Balkans: Women and Society in Yugoslavia and the Yugoslav Successor States (University Park, PA, 1999), 109-30; Sheri Kunovich, "The Representation of Polish and Czech Women in National Politics: Predicting Electoral List Position,” Comparative Politics 35, no. 3 (April 2003): 273-91; Richard Matland and Kathleen Montgomery, eds., Women's Access to Political Power in Post-Communist Europe (New York, 2003); Frances Millard, “The Representation of Women,” in Frances Millard, ed., Elections, Parties and Representation in Post-Communist Europe (New York, 2014), 184-223; Marilyn Rueschemeyer and Sharon Wolchik, eds., Women in Power in Post-Communist Parliaments (Bloomington, 2009); Steven Saxonberg, "Women in East European Parliaments," Journal of Democracy 11, no. 2 (April 2000): 145-58; Iulia Shevchenko, "Who Cares about Women's Problems? Female Legislators in the 1995 and 1999 Russian State Dumas," Europe-Asia Studies 54, no. 8 (December 2002): 1201-22.

7. On this topic, see Nanette Funk, "Women's NGOs in Central and Eastern Europe and the Former Soviet Union: The Imperialist Criticism,” in Jasmina Lukić, Joanna Regulska, and Darja Zaviršek, eds., Women and Citizenship in Central and Eastern Europe (Abingdon Oxon, Eng., 2006), 265-86; Kristen Ghodsee, "Feminism-by-Design: Emerging Capitalisms, Cultural Feminism, and Women's Nongovernmental Organizations in Postsocialist Eastern Europe,” Signs: Journal of Women in Culture and Society 29, no. 3 (Spring 2004): 727-53; Katja Guenther, "The Possibilities and Pitfalls of NGO Feminism: Insights from Postsocialist Eastern Europe," Signs: Journal of Women in Culture and Society 36, no. 4 (Summer 2011): 863-87; Hana Haškova and Zuzana Uhde, "Czech Women's NGOs: Women's Voices and Claims in the Public Sphere,” in Iveta Jusová and Jiina Šiklová, eds., Czech Feminisms: Perspectives on Gender in East Central Europe (Bloomington, 2016), 126-43; Julie Hemment, Empowering Women in Russia: Activism, Aid, and NGOs (Bloomington, 2007); Sarah Henderson, Building Democracy in Contemporary Russia: Western Support for Grassroots Organizations (Ithaca, 2003); Janet Elise Johnson, Gender Violence in Russia: The Politics of Feminist Intervention (Bloomington, 2009); Rebecca Kay, Russian Women and their Organizations: Gender, Discrimination and Grassroots Women's Organizations, 1991-96 (New York, 2000); Maria O’Reilly, Gendered Agency in War and Peace: Gender Justice and Women's Activism in Post-Conflict Bosnia-Herzegovina (London, 2018); Lisa McIntosh Sundstrom, Funding Civil Society: Foreign Assistance and NGO Development in Russia (Stanford, 2006); Patrice McMahon, "International Actors and Women's NGOs in Poland and Hungary," in Sarah E. Mendelson and John K. Glenn, eds., The Power and Limits of NGOs: A Critical Look at Building Democracy in Eastern Europe and Eurasia (New York, 2002), 29-53; Amanda Sloat, "The Rebirth of Civil Society: The Growth of Women's NGOs in Central and Eastern Europe.” European Journal of Women's Studies 12, no. 4 (November 2005): 437-52.

8. Contentious politics refers to "episodic, public, collective interaction among makers of claims and their objects when: (a) at least one government is a claimant, an object of claims, or a party to the claims, and (b) the claims would, if realized, affect the interests of at least one of the claimants or objects of claims." For details, see Sidney Tarrow, "Contentious Politics," in David A. Snow, Donatella della Porta, Bert Klandermans, and Doug McAdam, eds., The Wiley-Blackwell Encyclopedia of Social and Political Movements (Hoboken, NJ, 2013), at https://doi.org/10.1002/9780470674871.wbespm051 (last accessed June 8, 2018). 
The remainder of the article is organized as follows: section two discusses prior research on gender and protests at critical points in the region's political development, while section three focuses on women's activism in post-communist Ukraine. Next, the article describes the sample and presents original data from in-depth interviews. The concluding section underscores the significance of these findings and identifies avenues for future research.

\section{Gender and Protest in Comparative and Historical Perspective}

The role of women in democratization processes and contentious politics has long been neglected in the mainstream literature. In her analysis of the 1979 revolution in Iran and the 1989 revolutions in east central Europe, Valentine Moghadam pointed out the insufficient attention given to gender in extant sociological research on revolutionary processes and post-revolutionary transformations. ${ }^{9}$ Likewise, taking stock of political science literature in the early 1990s, Georgina Waylen criticized the "very little mention of gender or more specifically women" and called for a gendered analysis of democratization. ${ }^{10}$ Over the past two decades, however, there has been a growing appreciation of women's engagement in contentious politics. ${ }^{11}$

A prominent argument in this literature is that the politicization of motherhood "turns needs related to children into political demands and thus promotes political action."12 The essentialist definition of motherhood assumes that women's innate, fixed characteristics predetermine their primary function as caregivers for their progeny, which excludes women from active participation in the public sphere. ${ }^{13}$ In contrast, in her influential study of women's community work in low-income neighborhoods in New York City and Philadelphia, Nancy Naples develops the concept of activist mothering to broaden the traditional definition of mothering and encompass nurturing work not only for biologically- or legally-related children but also for the community as a whole. ${ }^{14}$ Likewise, Helen Icken Safa argues that increased participation of poor, urban Latin American women in social movements in the 1980s can be attributed to the redefinition and transformation of "their domestic role from one of private nurturance to one of collective, public protest, and in this way challenging the traditional seclusion of women into the private sphere of

9. Valentine M. Moghadam, "Gender and Revolutionary Transformation. Iran 1979 and East Central Europe 1989,” Gender and Society 9, no. 3 (June 1995): 328-58.

10. Georgina Waylen, "Women and Democratization: Conceptualizing Gender Relations in Transition Politics," World Politics 46, no. 3 (April 1994): 327-54, 327.

11. On this point, see Karen Beckwith, "Beyond Compare? Women's Movements in Comparative Perspective," European Journal of Political Research 37, no. 4 (January 2000): 431-68.

12. Graciela Di Marco, “Social Justice and Gender Rights,” International Social Science Journal 191 (2009): 43-55, 53.

13. Myrl Coulter, “Essentialism and Mothering,” In Andrea O’Reilly, ed., Encyclopedia of Motherhood vol. 1 (Thousand Oaks, CA, 2010), 357-59.

14. Nancy A. Naples, "Activist Mothering: Cross-Generational Continuity in the Community Work of Women from Low-Income Urban Neighborhoods," Gender and Society 6 no. 3 (September 1992): 441-63, 446. 
family." 15 Women's legitimization of civic activism with the help of their social identity as mothers has been found in diverse contexts. ${ }^{16}$ Fidelma Ashe, for example, shows how Irish women exploited cultural notions about the role of mothers to justify their involvement in mass protests. ${ }^{17}$ Scholars also find that women in the United States used the ethos of maternal identity as a rationale for their environmental-justice activism. ${ }^{18}$ Building upon extant research on women's activism in North America, western Europe, and Latin America, recent scholarship applies the notions of motherhood and mothering to analyze women's engagement in contentious politics in eastern Europe. ${ }^{19}$

A growing body of literature focuses on women's resistance to the communist regime. ${ }^{20}$ Based upon the memoirs of participants in the nationalist underground movement in western Ukraine, Oksana Kis demonstrates how women's involvement in guerilla warfare caused the contestation of traditional gender norms and the subordination of their personal lives to the national cause. ${ }^{21}$ Specifically, Kis finds that female insurgents postponed marriage and childbearing but subscribed to motherhood as a cultural value, assuming collective responsibility for the well-being of all children in their

15. Helen Icken Safa, "Women's Social Movements in Latin America," Gender and Society 4, no. 3 (September 1990): 354-69, 355.

16. See, for example, Sonia Alvarez, Engendering Democracy in Brazil: Women's Movements in Transition Politics (Princeton, 1990); Marguerite Guzman Bouvard, Revolutionizing Motherhood: The Mothers of the Plaza de Mayo (Wilmington, Del., 1994); Michelle Carreon and Valentine Moghadam, “'Resistance Is Fertile’: Revisiting Maternalist Frames across Cases of Women's Mobilization,” Women's Studies International Forum 51 (JulyAugust 2015): 19-30; Valeria Fabj, "Motherhood as Political Voice: The Rhetoric of the Mothers of Plaza de Mayo," Communication Studies 44, no. 1 (1993): 1-18; Jenny Irons, "The Shaping of Activist Recruitment and Participation: A Study of Women in the Mississippi Civil Rights Movement," Gender and Society 12, no. 6 (December 1998): 692-709; Nancy A. Naples, Grassroots Warriors: Activist Mothering, Community Work, and the War on Poverty (New York, 1998).

17. Fidelma Ashe, "Gendering Ethno-Nationalist Conflict in Northern Ireland: A Comparative Analysis of Nationalist Women's Political Protests,” Ethnic and Racial Studies 30 no. 5 (August 2007): 766-86, 773.

18. Shannon Elizabeth Bell and Yvonne A. Braun, "Coal, Identity, and the Gendering of Environmental Justice Activism in Central Appalachia," Gender and Society 24, no. 6 (December 2010): 794-813; Jennifer A. Peeples and Kevin M. DeLuca, "The Truth of the Matter: Motherhood, Community and Environmental Justice," Women's Studies in Communication 29, no. 1 (Spring 2006): 59-87.

19. The term "Eastern Europe" is here loosely used to refer to the post-communist region, with a geographical focus on central and eastern Europe.

20. Belinda Brown, The Private Revolution: Women in the Polish Underground Movement (London, 2003); Padraic Kenney, "The Gender of Resistance in Communist Poland," American Historical Review 104, no. 2 (April 1999): 399-425; Shana Penn, Solidarity's Secret: The Women Who Defeated Communism in Poland (Ann Arbor, 2006); Thomas Shriver, Alison Adams, and Rachel Einwohner, "Motherhood and Opportunities for Activism Before and After the Czech Velvet Revolution," Mobilization: An International Quarterly 18, no. 3 (September 2013): 267-88; Lavinia Stan, "Women as Anti-Communist Dissidents and Secret Police Collaborators," in Florentina Andreescu and Michael J. Shapiro, eds., Genre and the (Post-) Communist Woman: Analyzing Transformations of the Central and Eastern European Female Ideal (New York, 2015), 80-97.

21. Oksana Kis, "National Femininity Used and Contested: Women's Participation in the Nationalist Underground in Western Ukraine during the 1940s-50s," East/West: Journal of Ukrainian Studies 11, no. 2 (2015): 53-82, 74. 
community. Similarly, the Mothers of the Plaza de Mayo redefined the role of mothers in a patriarchal society and began to express concern about all missing persons, not just their biological children, under the military junta in Argentina. ${ }^{22}$

Another line of inquiry investigates women's activism during the transition from communism. ${ }^{23}$ Valerie Sperling, for example, provides a compelling analysis of Russian women's organizations in the 1990s, showing how the transition period created both opportunities and challenges for women activists. $^{24}$ The Committee of Soldiers' Mothers was one of the most active civic organizations in Russia during that period, especially with a start of military operations in the Chechen Republic and a spike in the violations of soldiers' rights. Empirical work on this Russian NGO indicates that the mothers' concern about the well-being of their sons provided an incentive for their civic engagement. ${ }^{25}$ Elena Zdravomyslova, for example, analyzes the organization's adoption of the "responsible motherhood" frame to redefine the concept of mothers' rights and use it against the military. ${ }^{26}$ In contrast, the Serbian anti-war group Women in Black framed its organization of silent vigils as "a conscious political choice" rather than a product of women's "natural" propensity for nurturing. ${ }^{27}$

22. On this point, see Viviana M. Abreu Hernandez, "The Mothers of La Plaza de Mayo: A Peace Movement," Peace and Change 27, no. 3 (July 2002): 385-411; Diana Taylor, "Making a Spectacle: The Mothers of the Plaza de Mayo," Journal of the Association for Research on Mothering 3, no. 2 (2001): 97-109.

23. Judy Root Aulette, "New Roads to Resistance and Participation: Polish Feminists in the Transition to Democracy," in Jill M. Bystydzienski and Joti Sekhon, eds., Democratization and Women's Grassroots Movements (Bloomington, 1999), 217-40; Lisa Baldez, "Women's Movements and Democratic Transition in Chile, Brazil, East Germany, and Poland," Comparative Politics 35, no. 3 (April 2003): 253-72; Mary Buckley, ed., Post-Soviet Women: From the Baltic to Central Asia (Cambridge, Eng., 1997), 141-200; Barbara Evans Clements, "Gains and Losses, 1991-2010," in her A History of Women in Russia: From Earliest Times to the Present (Bloomington, 2012), 286-315; Susan Gal and Gail Kligman, eds., Reproducing Gender: Politics, Publics, and Everyday Life after Socialism (Princeton, 2000); Jane S. Jacquette and Sharon L. Wolchik, eds., Women and Democracy: Latin America and Central and Eastern Europe (Baltimore, MD, 1998); Marilyn Rueschemeyer, "Women in East Germany: From State Socialism to Capitalist Welfare State," in Valentine Moghadam, ed., Democratic Reform and the Position of Women in Transitional Economies (Oxford, UK, 1993), 75-91; Tamar Sabedashvili, Gender and Democratization: The Case of Georgia, 1991-2006 (Tbilisi, 2007).

24. Valerie Sperling, Organizing Women in Contemporary Russia: Engendering Transition (Cambridge, Eng., 1999).

25. Anna Colin Lebedev, “From a Mother’s Worry to Soldiers' Mothers’ Action: Building Collective Action on Personal Concerns," in Risto Alapuro, Arto S. Mustajoki, and Pekka Pesonen, eds., Understanding Russianness (London, 2012), 84-98; Eva Maria Hinterhuher, "Between Neotraditionalism and New Resistance-Soldiers' Mothers of St. Petersburg," Anthropology of East Europe Review 19, no. 1 (2001): 139-52.

26. Elena Zdravomyslova, "Soldiers' Mothers Fighting the Military Patriarchy: ReInvention of Responsible Activist Motherhood for Human Rights' Struggle,” in Ilse Lenz, Charlotte Ullrich, and Barbara Fersch, eds., Gender Orders Unbound? Globalisation, Restructuring and Reciprocity (Opladen, Germany, 2007), 207-28.

27. Bojan Bilic, "Not in Our Name: Collective Identity of the Serbian Women in Black," Nationalities Papers 40, no. 4 (June 2012): 607-23, 611. 
A spate of recent work examines women and protests in repressive political regimes that have been installed in the post-Soviet region since the collapse of communism. ${ }^{28}$ In response to the entrenchment of authoritarian practices, women became involved in newly-formed pro-democracy movements and deployed innovative tactics against the regime. The Russian punk rock band Pussy Riot, for example, creatively challenged the patriarchal gender norms in Russian society and, among other things, staged a flashmob-style performance inside Moscow's Cathedral of Christ the Savior. ${ }^{29}$ As pointed out by Janet Elise Johnson, Pussy Riot exemplifies the development of "informal feminism" in Russia in the aftermath of state repression against "NGO feminism." ${ }^{30}$ Likewise, the Ukrainian women's group FEMEN, founded by Anna Hutsol, Oksana Shachko, Inna Shevchenko, and Oleksandra Shevchenko in 2008, adopted radical action to fight against patriarchy. ${ }^{31}$ In another political setting, focusing on post-1989 Poland, Joanna Regulska and Magdalena Grabowska also observe an increasing diversification of strategies pursued by women's NGOs and feminist groups. ${ }^{32}$ Nonetheless, despite the emergence of various feminist initiatives since the collapse of communism, the concept of feminism is ridden with controversy in the dominant public discourse. ${ }^{33}$

28. Steven Levitsky and Lucan Way develop the term "competitive authoritarianism" to define political regimes in which multiparty, multicandidate elections are regularly held, but the ruling elite violates democratic procedures to the extent that the turnover of power is hardly possible. Several former Soviet republics, including Georgia under Eduard Shevardnadze and Ukraine under Viktor Yanukovych, fit this description. For details, see Steven Levitsky and Lucan A. Way, Competitive Authoritarianism: Hybrid Regimes after the Cold War (Cambridge, Eng., 2010).

29. Emily Channell, "Is Sextremism the New Feminism? Perspectives from Pussy Riot and Femen," Nationalities Papers 42, no. 4 (July 2014): 611-14; Elizabeth Groeneveld, “Are We All Pussy Riot? On Narratives of Feminist Return and the Limits of Transnational Solidarity," Feminist Theory 16, no. 3 (December 2015): 289-307; Peter Rutland, "The Pussy Riot Affair: Gender and National Identity in Putin's Russia," Nationalities Papers 42, no. 4 (July 2014): 575-82; Vera Shevzov, "Women on the Fault-Lines of Faith: Pussy Riot and the Insider/Outsider Challenge to Post-Soviet Orthodoxy," Religion and Gender 4, no. 2 (2014): 121-44; Valerie Sperling, "Russian Feminist Perspectives on Pussy Riot," Nationalities Papers 42, no. 4 (July 2014): 591-603.

30. Janet Elise Johnson, "Pussy Riot as a Feminist Project: Russia's Gendered Informal Politics," Nationalities Papers 42, no. 4 (July 2014): 583-90.

31. Galia Ackerman, Femen (Cambridge, Eng., 2014); Cerelia Athanassiou and Jonah Bury, "On Caretakers, Rebels and Enforcers: The Gender Politics of Euro 2012," European Journal of Women's Studies 21, no. 2 (May 2014): 148-64; Marian J. Rubchak, "Seeing Pink: Searching for Gender Justice through Opposition in Ukraine," European Journal of Women's Studies 19, no. 1 (February 2012): 55-72; Jessica Zychowicz, "Performing Protest: Femen, Nation, and the Marketing of Resistance," Journal of Ukrainian Politics and Society 1, no. 1 (2015): 79-104.

32. Joanna Regulska and Magdalena Grabowska, "Post-1989 Women's Activism in Poland," in Joanna Regulska and Bonnie G. Smith, eds., Women and Gender in Postwar Europe: From Cold War to European Union (London, 2012), 212-30.

33. Agnieszka Graff, "Lost between the Waves? The Paradoxes of Feminist Chronology and Activism in Contemporary Poland," Journal of International Women's Studies 4, no. 2 (April 2003): 100-116; Alena Heitlinger, "Framing Feminism in Post-Communist Czech Republic," Communist and Post-Communist Studies 29, no. 1 (March 1996): 77-93; Laurie Occhipinti, “Two Steps Back?: Anti-Feminism in Eastern Europe,” Anthropology Today 12, no. 
Overall, there are multiple motivations for women's engagement in contentious collective action, lying at the heart of all social movements and revolutions. ${ }^{34}$ Some women might exploit the notion of motherhood to account for their activism. Others might explain their involvement in protest activity outside the framework of the mother's role in society. This study uses the case of women's activism during the EuroMaidan to examine why women in a repressive political regime engage in contentious politics.

\section{Women's Activism in Ukraine}

Women, albeit comprising nearly 54 percent of the country's total population, have been subject to a great deal of gender discrimination in Ukraine..$^{35}$ Ukraine ranked 57th out of 188 countries on the 2014 Gender Inequality Index, with a higher value signifying a higher level of inequality in achievement between women and men in three dimensions: reproductive health, empowerment, and the labor market. ${ }^{36}$ Similarly, the 2014 Global Gender Gap Index ranked Ukraine 56th out of 142 countries based upon a set of education, health, economic, and political criteria. ${ }^{37}$ Ukrainian women, on average, have a higher level of educational attainment than men. For example, women made up 52.3 percent of the student population in tertiary-level institutions during the 2013-14 academic year. ${ }^{38}$ Yet, women tend to earn less than their

6 (December 1996): 13-18; Anna Temkina and Elena Zdravomyslova, "Gender’s Crooked Path: Feminism Confronts Russian Patriarchy,” Current Sociology 62, no. 2 (March 2014): 253-70; Vikki Turbine, “Women's Human Rights in Russia: Outmoded Battlegrounds, or New Sites of Contentious Politics?” East European Politics 31, no. 3 (August 2015): 326-41.

34. Sidney G. Tarrow, Power in Movement: Social Movements and Contentious Politics, 3rd ed. (Cambridge, Eng., 2011), 7.

35. In 2014 Ukraine's total population was 45,245,900 people, including 24,327,600 women and 20,918,300 men. A higher proportion of women can be attributed in part to gender disparities in life expectancy. The average life expectancy was 76 years for women and 66 years for men in 2014. See the State Statistics Committee of Ukraine, at https:// ukrstat.org/uk/operativ/operativ2007/ds/nas_rik/nas_u/nas_rik_u.html (last accessed August 10, 2016). For a thorough analysis of gender and society in contemporary Ukraine, see Olena Hankivsky and Anastasiya Salnykova, eds., Gender, Politics, and Society in Ukraine (Toronto, 2012); Marian J. Rubchak, ed., Mapping Difference: The Many Faces of Women in Contemporary Ukraine (New York, 2011).

36. The level of reproductive health is measured with the help of two indicators: the maternal mortality ratio and the adolescent birth rate. Empowerment is measured by the share of parliamentary seats held by women and the share of the population with at least some secondary education. Labor market participation is measured as a proportion of women in the labor force within a country's working-age population. For details, see the United Nations Development Program, The 2015 Human Development Report (New York, 2015), at http://report.hdr.undp.org/ (last accessed August 10, 2016).

37. For details regarding the measurement of the Global Gender Gap Index, see Ricardo Hausmann, Laura Tyson, Yasmina Bekhouche, and Saadia Zahdi, “The Global Gender Gap Index 2014,” in The Global Gender Gap Report 2014 (World Economic Forum, 2014), 3-6, at http://reports.weforum.org/global-gender-gap-report-2014 (last accessed August 10, 2016).

38. Iryna Kohut, "Chym vidrizniaiutsia zhinky i choloviky: Pro gendernu (ne)rivnist v vyshchyi osviti," July 10, 2014, at http://www.cedos.org.ua/uk/discrimination/chym-vidrizniaiutsia-zhinky-i-choloviky-pro-hendernu-ne-rivnist-u-vyshchii-osviti (last accessed August 12, 2016). 
male peers. ${ }^{39}$ The average monthly wages were UAH 2,866 (\$362) for women and UAH 3,711 (\$469) for men in 2013, meaning that female full-time workers made seventy-seven cents for every dollar earned by men. ${ }^{40}$ Gender disparities in wages were even larger in higher-paying sectors of the economy and, for example, stood at 66.7 percent in the financial and insurance sectors..$^{41}$ Another socioeconomic trend in contemporary Ukraine is the feminization of poverty. ${ }^{42}$ Access to a smaller pool of economic resources puts women at a significant disadvantage in the political sphere.

To date, women's access to political power is dismally low. ${ }^{43}$ The share of women in Ukraine's national parliament, Verkhovna Rada, is consistently below ten percent in the post-Soviet period, ranging from 5.3 percent in 2002 to 9.4 percent in $2012 .{ }^{4}$ Women's representation was slightly higher at the local level, with 12 percent of seats held by women in provincial councils (oblasni rady) in 2010.45 Outside the legislative arena, women worked in the NGO sector to tackle a broad spectrum of issues, including domestic violence, human trafficking, and gender equality. According to some estimates, there were more than 700 women's organizations in Ukraine in the early 2010s. ${ }^{46}$ Furthermore, women became engaged in protest activity and participated in the Orange Revolution and the EuroMaidan. This section provides a succinct overview of extant scholarship on women's activism in Ukraine.

An influential body of research has shown that the notion of Berehynia, a pagan goddess of the hearth, affects the dominant construction of

39. On the gender wage gap in Ukraine, see Elizabeth Brainerd, "Women in Transition: Changes in Gender Wage Differentials in Eastern Europe and the Former Soviet Union," Industrial and Labor Relations Review 54, no. 1 (October 2000): 138-62; Norberto Pignatti, “Gender Wage Gap Dynamics in a Changing Ukraine," IZA Journal of Labor Development 1, no. 7 (December 2012): 1-44.

40. The estimates of the gender pay gap are based upon the authors' calculations. The data are retrieved from the online archive of the State Statistics Committee of Ukraine, "Average Monthly Wages and Salaries of Women and Men by Type of Economic Activity in 2013,” at http://www.ukrstat.gov.ua/operativ/operativ2013/gdn/Szp_ed/Szp_ed_e/Szp_ ed_2013_e.html (last accessed August 10, 2016). The exchange rate for Ukrainian national currency hryvnia (UAH) to US dollar was 7.9 in 2013, National Bank of Ukraine, "Ofitsiinyi kurs hryvni do inozemnykh valiut (serednii za period)," at https://bank.gov.ua/control/ uk/publish/category?cat_id=7693080 (last accessed August 10, 2016).

41. State Statistics Committee of Ukraine, “Average Monthly Wages and Salaries,” as n40 above.

42. For a detailed account of gender discrimination in the labor market, see: Ella Libanova, ed. Analytical Research on Women's Participation in the Labor Force in Ukraine (Kyiv, 2012), at https://www.idss.org.ua/monografii/2013_en_womens\%20participation. pdf (last accessed June 8, 2018).

43. For a recent overview of women's political representation, see Tamara Martsenyuk, Zhinky v ukrainskii politytsi: Vyklyky i perspektyvy zmin (Kyiv, 2015), at http://www. icps.com.ua/assets/uploads/files/gender_block_editfinal.pdf (last accessed June 8, 2018).

44. The data on women's political representation are retrieved from the Inter-Parliamentary Union, PARLINE Database, at http://www.ipu.org/parline-e/reports/2331_arc. htm (accessed August 10, 2016).

45. Ukrainskii zhinochyi fond, Genderna arifmetika vlasti (Kyiv, 2010), http://www. uwf.kiev.ua/files/arifmetika_ukr2010-1.pdf (last accessed August 10, 2016).

46. Liana Iatsenko, “Zhinochyi rukh Ukrainy: Etapy stanovlennia,” Naukovy zapysky $z$ ukrainiskoi istorii 21 (Pereiaslav-Khmelnytskyi State Pedagogical University named after Hryhorii Skovoroda, Department of History and Culture of Ukraine, 2008): 386-90, 388. 
women's identity in contemporary Ukraine. ${ }^{47}$ As a modern-day embodiment of Berehynia, women are expected to take care of their family and by extension safeguard the country's physical survival. The concept of Berehynia is also used to promote the woman's role in preserving Ukrainian culture. Solomea Pavlychko, for example, observes that references to Berehynia are woven into the dominant public discourse to propagate the idea of women as guardians of Ukrainian cultural heritage. ${ }^{48}$ Based upon her ethnographic work in Cherkasy oblast, Martha Kichorowska Kebalo concludes that the Berehynia discourse made women "subjected to a deceptive dual standard whereby they are encouraged to think of themselves as being empowered through motherhood and the sphere of cultural reproduction, even as they are simultaneously openly oppressed by new social patterns revealed in a litany of negative indicators (unemployment, representation in decision making positions, business management, and others). ${ }^{349}$ In light of this dominant public discourse, "traditional” gender roles refer to women's responsibilities for household chores and childrearing and men's primary function as a breadwinner. Women's engagement in politics falls out of the scope of "traditional" gender roles, but there have been some attempts to change the power imbalances between women and men.

Prolific research has examined women's participation in legislative politics. ${ }^{50}$ Based upon the analysis of biographical information of 1,768 parliamentarians elected between 1990 and 2007, Elena Semenova concludes that the introduction of the proportional electoral system did not lead to a higher level of women's representation in the national parliament. ${ }^{51}$ In addition, few

47. See, for example, Oksana Kis, "Choosing without Choice: Predominant Models of Femininity in Contemporary Ukraine,” in Ildikó Asztalos Morell, Madeleine Hurd, Helen Carlbäck and Sara Rastbäck, eds., Gender Transitions in Russia and Eastern Europe (Stockholm, 2005), 105-36; Marian J. Rubchak, "Christian Virgin or Pagan Goddess: Feminism versus the Eternally Feminine in Ukraine," in Rosalind Marsh, ed., Women in Russia and Ukraine (New York, 1996), 315-30; Marian J. Rubchak, "In Search of a Model: Evolution of a Feminist Consciousness in Ukraine and Russia," European Journal of Women's Studies 8, no. 2 (May 2001): 149-60.

48. Solomea Pavlychko, "Feminism in Post-Communism Ukrainian Society," in Rosalind Marsh, ed., Women in Russia and Ukraine (New York, 1996), 305-15.

49. Martha Kichorowska Kebalo, "Personal Narratives of Women's Leadership and Community Activism in Cherkasy Oblast” (PhD diss., City University of New York, 2011), 477.

50. Anna Andreenkova, "Women's Representation in the Parliaments of Russia and Ukraine: An Essay in Sociological Analysis,” Sociological Research 41, no. 2 (Mar/ Apr 2002): 5-25; Sarah Birch, "Women and Political Representation in Contemporary Ukraine," in Richard E. Matland and Kathleen A. Montgomery, eds., Women's Access to Political Power in Post-Communist Europe (Oxford, 2003), 130-53; Tatiana Kostadinova, "Ethnic and Women's Representation under Mixed Election Systems," Electoral Studies 26, no. 2 (June 2007): 418-31; Tetiana Kostiuchenko, Tamara Martsenyuk, and Svitlana Oksamytna, "Women Politicians and Parliamentary Elections in Ukraine and Georgia in 2012," East/West: Journal of Ukrainian Studies 2, no. 2 (2015): 83-110; Anastasiya Salnykova, "Electoral Reforms and Women's Representation in Ukraine," in Olena Hankivsky and Anastasiya Salnykova, eds., Gender, Politics, and Society in Ukraine (Toronto, 2012).

51. Elena Semenova, "Patterns of Parliamentary Representation and Careers in Ukraine: 1990-2007," East European Politics and Societies 26, no. 3 (August 2012): 538-60, 549. 
women were promoted to leadership positions inside political parties. Among Ukraine's most successful female politicians was Yulia Tymoshenko, leader of the political party Batkivshchyna (Fatherland), former minister of energy, former prime minister, and a presidential candidate. Given Tymoshenko's prominent position in Ukrainian politics, scholars have analyzed how she utilized femininity to advance her political career..$^{52}$ Oksana Kis, for example, argues that Tymoshenko's popularity can be attributed to a savvy combination of two predominant modes of femininity-Berehynia and Barbie-and her projection of herself as both "a virtuous mother of her nation" and "a national sex symbol." 53 Tymoshenko performed these dual roles without speaking out in favor of women's rights. ${ }^{54}$

Another substantial body of literature has analyzed women's involvement in civic associations. ${ }^{55}$ Within this literature, a great deal of attention has been devoted to interactions between local NGOs, transnational feminist organizations, and the international donor community. In her extensive work on women's organizations in the post-Soviet period, Alexandra Hrycak identifies substantial differences between the western understanding of women's empowerment and local conceptions of women's activism. ${ }^{56}$ Furthermore, Tatiana Zhurzhenko argues that intra-country differences in the development of the Ukrainian women's movement compounded a shift from a western

52. Alexandra Hrycak, "The “Orange Princess" Runs for President: Gender and the Outcomes of the 2010 Presidential Election," East European Politics and Societies 25, no. 1 (January 2011): 68-87; Sook-Hi Yang and Younyung Cho, "A Study on the Women Political Leaders' Fashion Style for Role Enactment-Focusing on Yulia Tymoshenko," The Research Journal of the Costume Culture 19, no. 1 (2011): 104-11; Tatiana Zhurzhenko, "Julia Tymoshenko's Two Bodies,” in Maria Raicheva-Stover and Elza Ibroscheva, eds., Women in Politics and Media: Perspectives from Nations in Transition (New York, 2014).

53. Oksana Kis, "Beauty Will Save the World! Feminine Strategies in Ukrainian Politics and the Case of Yulia Tymoshenko," Spaces of Identity 7, no. 2 (2007): 31-75, at http:// www.yorku.ca/soi/_Vol_7_2/_HTML/Kis.html (last accessed August 16, 2016).

54. On this point, see Tamara Martsenyuk, "Women's Top-Level Political Participation: Failures and Hopes of Ukrainian Gender Politics," in Marian J. Rubchak, ed., New Imaginaries: Youthful Reinvention of Ukraine's Cultural Paradigm (New York, 2015), 33-52.

55. Martha Bohachevsky-Chomiak, "Women's Organizations in Independent Ukraine," in Sharon Wolchik and Volodymyr Zviglyanich, eds., Ukraine: The Search for a National Identity (Lanham, MD., 2000), 265-84; Alexandra Hrycak, "From Mothers' Rights to Equal Rights: Post-Soviet Grassroots Women's Associations,” in Nancy A. Naples and Manisha Desai, eds., Women's Community Activism and Globalization: Linking the Local and Global for Social Change (New York, 2002), 64-82; Scott Orr, "Identity and Civil Society in Poland, Latvia, and Ukraine: Women's NGOs," East European Politics and Societies 22, no. 4 (September 2008): 856-78; Sarah Phillips, "Civil Society and Healing: Theorizing Women's Social Activism in Post-Soviet Ukraine," Ethnos 70, no. 4 (December 2005): 489-514; Sarah Phillips, Women's Social Activism in the New Ukraine: Development and the Politics of Differentiation (Bloomington, 2008); Nadia Shapkina, "Ruling vs. Dialogical Relations: NGOs, Women, and Institutional Power in Anti-Trafficking Campaigns in Russia and Ukraine," Gender in Postsocialist Eastern Europe and the Former Soviet Union, a special issue of Anthropology of East Europe Review 28, no. 1 (2010): 332-54.

56. See, for example, Alexandra Hrycak, "From Global to Local Feminisms: Transnationalism, Foreign Aid and the Women's Movement in Ukraine," in Sonita Sarker, ed., Sustainable Feminisms, Advances in Gender Research, vol. 11 (2007), 75-93; Hrycak, "Seeing Orange: Women's Activism and Ukraine’s Orange Revolution,” Women's Studies Quarterly 35, no. 3-4 (Fall-Winter 2007): 208-25. 
conceptualization of feminism to the invention of "the myth of the 'strong' Ukrainian woman and of the 'matriarchal' roots of Ukrainian culture." 57 Using an ethnographic approach, Sarah Phillips uncovers how women activists became exposed to the western feminist discourse and "reproduced it in culturally specific ways." ${ }^{58}$ In particular, FEMEN concocted an interpretation of feminism that produced mixed reactions in Ukraine and abroad. ${ }^{59}$ Theresa O'Keefe, for example, argues that the subversive use of naked bodies might entail the group's "reproduction of patriarchal, hegemonic norms." ${ }^{\circ 0}$ On a more optimistic note, Jessica Zychowicz concludes that FEMEN might stimulate "greater pluralism within feminist studies and practices in Ukraine."61

There exists scant empirical work on women's participation in the Orange Revolution. ${ }^{62}$ The 2004 protest campaign was triggered by large-scale electoral fraud during the presidential elections. ${ }^{63}$ According to some estimates, nearly one-fifth of the country's population joined demonstrations in the capital city or their hometowns during the Orange Revolution. ${ }^{64}$ Hrycak finds that most women participated in the Orange Revolution "by performing care work" for protesters, especially out-of-town youth. ${ }^{65}$ Compared to the Orange Revolution, the EuroMaidan was marked by a greater visibility of women's

57. Tatiana Zhurzhenko, "Ukrainian Feminism(s): Between Nationalist Myth and Anti-Nationalist Critique,” IWM Working Paper No. 4 (Vienna, 2001), 1.

58. Sarah Phillips, "NGOs in Ukraine: The Makings of a 'Woman's Space'?" in "Why Post-Socialism is Good to Think: The Anthropology of Transforming States," special issue of Anthropology of East Europe Review 18, no. 2 (2000): 23-28, 24.

59. Natalia Chermalykh, "FEMEN: Promovysta estetyka, nevyrazna polityka," Gendernyi zhurnal "Ia" 32 (2013): 29-31, at http://krona.org.ua/assets/files/journal/Gendernyi-zhurnal-Ya-32-2013.pdf (last accessed June 1, 2016); Julia Khrebtan-Hörhager and Iuliia Kononenko, "Of Fighters and Frames: Femen's Corporeality Between the Old, the New, the Yellow and the Blue," Journal of Intercultural Communication Research 44, no. 3 (September 2015): 224-51; Maria Mayerchyk and Olha Plakhotnik, "Radykalnyi Femen i novyi zhinochyi aktyvizm," Krytyka 11 (December 2010): 7-10, at https://krytyka.com/ ua/articles/radykalni-femen-i-novyy-zhinochyy-aktyvizm (last accessed June 1, 2016); Camilla M. Reestorff, "Mediatised Affective Activism: The Activist Imaginary and the Topless Body in the Femen Movement," Convergence: The International Journal of Research into New Media Technologies 20, no. 4 (November 2014): 478-95.

60. Theresa O’Keefe, "My Body Is My Manifesto! SlutWalk, FEMEN and Femmenist Protest," Feminist Review 107 (2014): 1-19, 1.

61. Jessica Zychowicz, "Two Bad Words: FEMEN and Feminism in Independent Ukraine," Anthropology of East Europe Review 29, no. 2 (2011): 215-27, 217.

62. Alexandra Hrycak, "Gender and the Orange Revolution," Journal of Communist Studies and Transition Politics 23, no. 1 (March 2007): 152-79; Alexandra Hrycak, "Orange Harvest?: Women's Activism and Civil Society in Ukraine, Belarus and Russia since 2004," Canadian-American Slavic Studies 44, no. 1-2 (2010): 151-77.

63. For an in-depth treatment of this topic, see Anders Åslund and Michael McFaul, eds., Revolution in Orange: The Origins of Ukraine's Democratic Breakthrough (Washington, DC, 2006); Paul D'Anieri, ed., Orange Revolution and Aftermath: Mobilization, Apathy, and the State in Ukraine (Washington, DC; Baltimore, MD, 2010).

64. Mark Beissinger, "Mechanisms of Maidan: The Structure of Contingency in the Making of the Orange Revolution," Mobilization: An International Quarterly 16, no. 1 (February 2011): 28-29; Viktor Stepanenko, "How Ukrainians View their Orange Revolution: Public Opinion and the National Peculiarities of Citizenry Political Attitudes," Demokratizatsiya: Journal of Post-Soviet Democratization 13, no. 4 (Fall 2005): 595-616, 597.

65. Hrycak, “Seeing Orange,” 216. 
initiatives aimed at gender equality on the Maidan and more broadly in Ukrainian society. ${ }^{66}$

Over the past few years, Ukrainian journalists and writers gathered memoirs of EuroMaidan participants to document extraordinary narratives of people's power and dignity at a critical juncture in Ukrainian history. ${ }^{67}$ For example, well-known Ukrainian poet and writer Oksana Zabuzhko, in collaboration with her colleagues, compiled an anthology of social media postings by EuroMaidan witnesses to capture a broad spectrum of their emotions and chronicle Ukrainian history in the making. ${ }^{68}$ To challenge a media bias in the coverage of the revolutionary situation-over-reporting of men's presence on the barricades and women's work in the kitchen-and underscore women's diverse contributions to the EuroMaidan, Iryna Virtosu published a collection of interviews with seventeen women activists. ${ }^{69}$ One of Virtosu's interviewees-Olena Shevchenko, a member of the women's squad (Zhinocha sotnia) named after Olha Kobylianska-conveyed the book's main message by stating that "heroism manifests itself not only in standing on the barricades, but also in covering the events, defending detainees in courts, taking part in the AutoMaidan [a civic initiative organized by automobile drivers], and carrying out educational work."70

Furthermore, a flurry of academic research has analyzed women's activism during the EuroMaidan..$^{71} \mathrm{~A}$ central debate in this literature revolves around the extent of women's success in overcoming patriarchal gender norms on the Maidan. Olesya Khromeychuk finds that some women expected and accepted

66. For a comparison of women's engagement in the Orange Revolution and the EuroMaidan, see Maria Dmitrieva, "Zhinky na Maidani: Stari mikhi, nove vino," May 16, 2014, at http://krona.org.ua/zhinki-na-majdani-stari-mixi-nove-vino.html (last accessed June 1, 2016).

67. Kristina Berdyns'kykh, Ieliudu: Tepli istorii z Maidanu (Kyiv, 2014); Sonia Koshkina, Maidan: Neraskazannaia istoria. Glavnoe rassledovanie sobytii Revoliutsii (Kyiv, 2015); Antin Mukharskyi, Maidan: (R)Evoliutsiia dukhu (Kyiv, 2014); Tetiana Pushnova and Artem Chekh, eds., 94 dni: Evromaidan ochyma TSN (Kyiv, 2014).

68. Oksana S. Zabuzhko and Tetiana Teren, eds., Litopys samovydavtsiv: Dev'iat misiatsiv ukrainskogo sprotyvu (Kyiv, 2014).

69. Iryna Virtosu, ed., Maidan: Zhinocha sprava (Kyiv, 2014), at https://www.uwf.org. ua/files/20140604104737967428maydan_web.pdf (last accessed June 18, 2018).

70. Virtosu, Maidan: Zhinocha sprava, 17.

71. Emily S. Channell-Justice, “We're Not Just Sandwiches”: Europe, Nation, and Feminist (Im)Possibilities on Ukraine’s Maidan," Signs: Journal of Women in Culture and Society 42, no. 3 (Spring 2017): 717-41; Anna Gritsenko, "Kak Evromaidan otpravlial zhenshchin na kukhniu," Gendernyi zhurnal "Ia" 36 (2014): 22-26, at http://krona.org.ua/assets/files/ journal/Gendernyi-zhurnal-Ya-36-2014.pdf (last accessed June 16, 2018); Olesya Khromeychuk, "Negotiating Protest Spaces on the Maidan: A Gender Perspective," Journal of Soviet and Post-Soviet Politics and Society 2, no. 1 (2016): 9-47; Tamara Martsenyuk, "Gender and Revolution in Ukraine: Women's Participation in Euromaidan Protests in 2013-2014," Perspectives on Europe 44, no. 2 (Autumn 2014): 15-23; Olga Onuch and Tamara Martsenyuk, "Mothers and Daughters of the Maidan: Gender, Repertoires of Violence, and the Division of Labour in Ukrainian Protests," Social, Health, and Communication Studies Journal 1, no. 1 (November 2014): 105-126, at https://journals.macewan.ca/shcsjournal/article/ view/248 (last accessed June 18, 2018); Sarah Phillips, “The Women’s Squad in Ukraine's Protests: Feminism, Nationalism, and Militarism on the Maidan," American Ethnologist 41, no. 3 (August 2014): 414-26. 
"the performance of traditionally feminine gender roles on the Maidan," while others challenged a gender-based division of labor. ${ }^{72}$ Based upon twenty-two focused interviews with EuroMaidan participants between April and August 2014, Sabine Rossmann concludes that women, with the exception of a minority of young women, "did not challenge their 'traditional' role as men's helpmates but participated on the basis of gendered social roles." 73 In contrast, Tamara Martsenyuk argues that Ukrainian women found niches for egalitarian participation and should be regarded as "makers," rather than "helpers" of the revolution. ${ }^{74}$ To some extent, women's roles on the Maidan-gendered or not-were shaped by their motivations for protesting.

This study primarily speaks to a strand of research on determinants of citizens' engagement in contentious politics. Most analysts concur that the EuroMaidan was spearheaded by the middle class. ${ }^{75}$ Volodymyr Paniotto, for example, finds that 64 percent of protesters received higher education and an additional 12 percent were university students. ${ }^{76}$ Numerous reports also indicate that young people played a vital role in the EuroMaidan, especially during its initial phase. ${ }^{77}$ Notably, the protest campaign was marked by the cross-generational exchange of expertise in nonviolent action, whereby veterans of the Revolution on the Granite (the 1990 student hunger strike in Soviet Ukraine) and the Orange Revolution (post-election protests in 2004) shared their experience with a younger generation of protesters. The article contributes to this line of inquiry by focusing on women's protest behavior.

72. Olesya Khromeychuk, "Gender and Nationalism on the Maidan," in David Marples and Frederick Mills, eds., Ukraine’s Euromaidan (Stuttgart, 2015), 129.

73. Sabine Rossman, “'To Serve Like a Man'-Ukraine’s Euromaidan and the Questions of Gender, Nationalism and Generational Change," in Matthias Schwartz and Heike Winkel, eds., Eastern European Youth Cultures in a Global Context (New York, 2016), 213.

74. Tamara Martsenyuk, "Gender Issues in Ukraine: Were the EuroMaidan Protests Patriarchal or Egalitarian?" in Anti-Gender Movements on the Rise? Strategising for Gender Equality in Central and Eastern Europe (Berlin, 2015), 73-81, at https://www.boell.de/ en/2015/04/21/anti-gender-movements-rise (last accessed August, 26 2016).

75. Nadia Diuk, "Euromaidan: Ukraine’s Self-Organizing Revolution,” World Affairs 176, no. 6 (March/April 2014): 9-16; Mykola Riabchuk and Andrej Lushnycky, "Ukraine’s Third Attempt," in Viktor Stepanenko and Yaroslav Pylynskyi, eds., Ukraine after the Euromaidan: Challenges and Hopes (Bern, Switz., 2015), 47-58; Olga Onuch, "Who Were the Protesters?” Journal of Democracy 25, no. 3 (July 2014): 44-51; Anastasiya Ryabchuk, "Right Revolution? Hopes and Perils of the Euromaidan Protests in Ukraine," Debatte: Journal of Contemporary Central and Eastern Europe 22, no. 1 (2014): 127-34.

76. Vladimir Paniotto, "Ukraina: Evromaidan," Vestnik obshchestvennogo mnenia 116, no. 3-4 (2013): 5, at http://www.levada.ru/sites/default/files/paniotto.pdf (last accessed June 19, 2018).

77. On the role of the young generation, see Oksana Khmeliovska, "Sotsiolog pro uchasnykiv Evromaidanu: Molod, iaka pragne zhyty, a ne vyzhyvatu," Tyzhden, November 27, 2013, at http://tyzhden.ua/News/95012; Nina Khodorivska, "Studentska Asambleia: Desiatok malenkykh revoliutsii,” Spilne: Journal of Social Critique 9 (2015): 135-43, at https://commons.com.ua/uk/studentska-asambleya-desyatok-malenkih-revolyutsij/; Lidia Surzhyk and Oksana Onyshchenko, “Studentskii Evromaidan: Krov i grim,” Dzerkalo tyzhnia, December 6, 2013, at http://gazeta.dt.ua/EDUCATION/studentskiy-yevromaydankrov-i-grim-_.html; Halyna Tytysh, "'Ia divchunka. Ia ne khochu sukniu, ia khochu zminyty tsiu systemu': Molod, iaka tvoryt myrnyi protest," Ukrainska Pravda, December 19, at http://life.pravda.com.ua/society/2013/12/19/146507/ (last accessed February 4, 2017). 


\section{Methodology}

We use in-depth interviewing as a data collection method, since it enables us to gain a more nuanced understanding of women's motivations for protesting than a large-N survey consisting of multiple-choice questions. ${ }^{78}$ Interviews consisted of open-ended questions that prompted women to narrate how and why they became engaged in the EuroMaidan. Given the open-ended nature of the interview questions, interviewees could mention more than one reason for their civic engagement. The average length of the interview was thirty minutes. Most interviews were conducted in Ukrainian during one of the author's field trips to Ukraine between March 2015 and March 2016, and several interviews were completed via Skype. The interviews were transcribed and human coded to identify various motivations for women's engagement in the EuroMaidan.

A total of thirty-seven female protesters were interviewed. The respondents were recruited using the snowball sampling method. This sampling method is especially appropriate when the population under study-"ordinary citizens"-is not easily identifiable. ${ }^{79}$ We sought to recruit a sufficiently diverse initial set of respondents so that the sample would capture women with different sociodemographic characteristics. The interviewees ranged in age from sixteen to seventy-one, with the mean age of 30.5. ${ }^{80}$ Respondents had different levels of educational attainment, including high school, incomplete higher education, and advanced graduate degrees. They all resided in Kyiv during the protest events, although many were born outside the capital city and moved there to receive higher education or seek employment. The pseudonyms are reported in the article to protect the interviewees' identity.

It should be born in mind that the sample is not representative of the total population of female participants in the protest campaign. As seen in Table 1, the sociodemographic profile of the interviewed women is slightly different from a sample of protesters surveyed by the Ilko Kucheriv Democratic Initiatives Foundation (DIF) and the Kyiv International Institute of Sociology (KIIS) on December 7-8, 2013. Our sample has a fourteen percent higher proportion of sixteen-twenty-nine-year-old respondents and thus a slightly higher percentage of university students. The DIF/KIIS questionnaire did not include survey items about the respondent's marital status and children. More than half of the interviewed women in our sample were single, and only 37.8 percent of the interviewees had children. A possible implication of an overrepresentation of younger protesters in our sample might be a lower salience of mothering as an incentive for protest behavior. It should also be noted that

78. On the use of in-depth interviewing in social movement research, see Kathleen Blee and Verta Taylor, "Semi-Structured Interviewing in Social Movement Research," in Bert Klandermans and Suzanne Staggenborg, eds., Methods of Social Movement Research (Minneapolis, 2002), 92-117.

79. On the political significance of ordinary citizens, see Nancy Bermeo, Ordinary People in Extraordinary Times: The Citizenry and the Breakdown of Democracy (Princeton, NJ, 2003); Christian Welzel and Ronald Inglehart, "The Role of Ordinary People in Democratization," Journal of Democracy 19, no. 1 (January 2008): 126-40.

80. For the sake of consistency, the respondent's age at the start of the EuroMaidan is reported throughout the article. 
Table 1

Sociodemographic Profile of Women Protesters

\begin{tabular}{lcc}
\hline & Our Sample & DIF/KIIS Sample \\
\hline Age & 56.8 & 42.9 \\
$16-29$ & 37.8 & 42.7 \\
$30-55$ & 5.4 & 14.4 \\
56 and older & & \\
Education & 59.5 & 70.5 \\
Received Higher Education & 27.0 & 17.5 \\
Students in Tertiary Education & & \\
Marital Status & 56.8 & N/A \\
Single & 29.7 & \\
Married & 10.8 & \\
Divorced & 2.7 & \\
Widowed & 37.8 & N/A \\
Have child(ren) & 100 & 65.5 \\
Place of Residence - Kyiv (2013) & 37 & 454 \\
Number of respondents & & \\
\hline
\end{tabular}

Note: Percentages are reported in the table.

our sample includes only women residing in Kyiv during the EuroMaidan. In contrast, DIF/KIIS finds that 35.5 percent of women came from other locales to the capital city for the sole purpose of participation in the protest campaign. Forty-eight percent of out-of-town protesters were thirty years old or older. As a result, our sample might not have captured female protesters who had committed a larger amount of time and money to join the EuroMaidan.

The respondents performed a wide range of functions during the EuroMaidan. Some women were responsible for the provision of food and first aid to protesters. Others dealt with logistics, fundraising, and public relations to maintain the encampment's infrastructure. The interviewed activists, for example, coordinated the dissemination of protest-related information and organized public lectures on the premises of the encampment. One of the interviewees belonged to a group of university students who held poetry readings on the Maidan. "Like [Vladimir] Maiakovskii and his generation, we felt like revolutionary poets, capable of changing the world with our words," recalled eighteen-year-old Ganna, an undergraduate student majoring in literature. ${ }^{81}$ Among the respondents were also members of the AutoMaidan and Zhinocha sotnia. ${ }^{82}$ The interview data suggest that a gender-based division of labor was imposed upon women on the Maidan. Some women challenged the notion of "traditional" gender roles, however, and the emergence of a women's squad is a vivid example of this. In the words of a woman activist, "no matter which

81. Ganna, interview, Kyiv, March 21, 2016.

82. The Ukrainian word sotnia literally means a hundred. It also refers to a military unit formed by the Zaporozhian Cossacks in the sixteenth century. Over the course of the EuroMaidan, protesters self-organized into sotnias to perform a variety of functions. 
roles-traditional, nontraditional, interesting, difficult roles-[woman performed] it is important to bear in mind that nobody has a right to reduce their role to maintenance work." 83

\section{Findings}

Table 2 summarizes the main motivations for women's engagement in the EuroMaidan. As seen in column 1, the interviewees reported a host of reasons for protesting, including civic duty, solidarity with protesters, motherhood, and professional service. The most frequently cited motivation for women's activism was profound dissatisfaction with the incumbent government. Citizens' grievances arose from the government's utmost disrespect for human rights, disproportionate police violence against protesters, rampant corruption, and scarce job opportunities. The president's decision to abandon a trade agreement with the EU was widely seen as the final straw, rather than the sole reason for contentious collective action. Another oft-cited motivation for protesting was solidarity with relatives, friends, and colleagues who joined the protest campaign. Moreover, the notion of activist mothering provided a powerful incentive for political engagement, especially among women with child-rearing experience. As shown in column 2, a quarter of the interviewees looked upon their participation in the protest campaign as fulfillment of their civic duty. Furthermore, some women came to the Maidan out of desire to put their professional skills to use. Concern over gender equality in Ukrainian society was rarely mentioned as an incentive for women's initial involvement in the EuroMaidan. It must also be noted that approximately twothirds of the interviewed women provided multiple reasons for protesting, so the above-mentioned motivations should be treated as complimentary, rather than self-exclusive.

Public disapproval of the president's rejection of a free trade agreement with the EU was a major reason for the start of mass protests in November 2013. For example, twenty-six-year-old Ruslana said:

When I joined, it was a question of being tied to Russia like to an old log, or to finally strengthen ties with the EU. Russia is an authoritarian country, it bears no promise of a better economy or democracy. EU-orientation is the best route for Ukraine. I want my kids to have a European standard of living, not whatever we have now. ${ }^{84}$

Among the perceived positive benefits of trade liberalization with the EU were better prospects for the preservation of families torn apart by labor migration. Fifty-year-old Sophia looked upon the trade agreement as a chance for improved family relations in migrant-sending households:

In fall 2013 I was closely following political developments over the EU trade deal. It meant so many things to different people. Due to a lack of job prospects and scarcity of ways to make money and support one's family, many families are split apart. One parent, usually the father, but sometimes the

83. Iryna Virtosu, ed., Maidan: Zhinocha sprava, 18.

84. Ruslana, interview, Kyiv, March 22, 2015. 
Table 2

Women's Motivations for Protesting

\begin{tabular}{|c|c|c|}
\hline Motivation & $\begin{array}{l}\text { Percentage of } \\
\text { Respondents }\end{array}$ & Illustrative Interview Quotes \\
\hline $\begin{array}{l}\text { Dissatisfaction with the } \\
\text { Government }\end{array}$ & 60 & $\begin{array}{l}\text { "I worked in a government agency, and I saw } \\
\text { firsthand a hideous level of cronyism and cor- } \\
\text { ruption. There was a pervasive culture of im- } \\
\text { munity; you could get away with anything you } \\
\text { had done as long as you were on good terms } \\
\text { with people at the top... I went to the Maidan } \\
\text { on the very first night because the EU deal was } \\
\text { the last straw." (Yaroslava) }\end{array}$ \\
\hline $\begin{array}{l}\text { Solidarity with } \\
\text { Protesters }\end{array}$ & 32 & $\begin{array}{l}\text { "I went to the square because my students had } \\
\text { gone there. And they were in danger and in } \\
\text { need of mass support." (Bohdana) }\end{array}$ \\
\hline Motherhood & 27 & $\begin{array}{l}\text { "Women are first and foremost mothers, and } \\
\text { it is important to us which kind of country our } \\
\text { children will live in." (Melaniia) }\end{array}$ \\
\hline Civic Duty & 24 & $\begin{array}{l}\text { "I went there [to the Maidan] because as a } \\
\text { citizen of this country it is my duty to do ev- } \\
\text { erything in my power to improve it, and the } \\
\text { Maidan embodied people's hope for that." } \\
\text { (Halyna) }\end{array}$ \\
\hline EU Integration & 22 & $\begin{array}{l}\text { "I don't want to live in a country like Russia, } \\
\text { and the decision to reject the EU deal in favor } \\
\text { of Russia was appalling to me. It felt like we } \\
\text { were a step away from becoming North Korea." } \\
\text { (Larysa) }\end{array}$ \\
\hline Professional Service & 11 & $\begin{array}{l}\text { "I am trained as a psychologist. I first went to } \\
\text { the Maidan to satisfy my professional curios- } \\
\text { ity, and stayed because I realized I could be } \\
\text { of help. My role was very important because } \\
\text { people were deeply affected by the events un- } \\
\text { folding in front of them." (Daryna) }\end{array}$ \\
\hline $\begin{array}{l}\text { Personal/Professional } \\
\text { Curiosity }\end{array}$ & 11 & $\begin{array}{l}\text { "Social media and TV news channels gave } \\
\text { conflicting accounts of what was happening. } \\
\text { There was no way to sort it out without going } \\
\text { to the Maidan and figuring things out for my- } \\
\text { self." (Tetiana) }\end{array}$ \\
\hline Gender Equality & 8 & $\begin{array}{l}\text { "Women are mothers, but also citizens. And } \\
\text { many people can't get it into their heads that } \\
\text { we can do more than just wipe up snotty } \\
\text { noses." (Viktoriia) }\end{array}$ \\
\hline
\end{tabular}

Note: The interviewees could report more than one motivation for their engagement in the EuroMaidan so the total is more than 100 percent. 
mother, or both, are forced to go abroad and do manual, denigrating jobs, just to make ends meet. What kind of marriage is it when the father is absent for years at a time? What kind of family is it? More importantly, what do children learn about family relations, love, responsibility, in torn families like these? It is heartbreaking, it is awful . . . the EU trade deal would open up a lot of economic prospects for people, and possibly alleviate Ukraine's many problems. It would also allow people to visit their families, therefore preserving at least some form of a family unit. ${ }^{85}$

Beyond the disapproval of the then-government's foreign policy priorities, a slew of political, socioeconomic, and cultural issues alienated women from the incumbent government and drove them into the street. Protesters found appalling the quality of governance under Yanukovych. As thirty-one-yearold Ivanna put it, "Murderers and degenerates were in power, and I could not stand by and watch them destroy my motherland." ${ }^{86}$ Specifically, a dearth of job opportunities and the strangulation of entrepreneurship were sources of concern for many protesters. Olena, a seventeen-year-old computer science student, discussed her dissatisfaction with the government on economic grounds:

As a software specialist [programist], I am very aware of how our government stifles creativity and life in general, particularly for young people. If I had a chance to study abroad, I would learn more, and I would also make so much more money. And here, not only people laugh at me for being a girl and a computer geek, but I don't get any professional respect either. There is a term aitishnik [IT specialist]. Have you heard of it? That's how people in this country think of software specialists because the concept of a start-up is like a fantasy here. Aitishnik is someone who installs Windows on your laptop and downloads a new anti-virus to get rid of all the evidence that you have been illegally downloading music on your work computer. It's a joke. There is no innovation here, no creativity. You are punished for trying to make something of yourself. This is not a good environment to live in. So I went and protested, and yeah, threw some bricks here and there. ${ }^{87}$

Moreover, corruption was a major source of political discontent among EuroMaidan participants. ${ }^{88}$ The incidence of corruption reached enormous proportions under Yanukovych, and it had a profound impact on the lives of ordinary citizens. ${ }^{89}$ For example, Yaryna, an eighteen-year-old native of Volyn oblast, Ukraine's north-western region on the border with Poland, recalled how corruption in the police engendered a climate of lawlessness

85. Sophia, interview, Kyiv, January 12, 2016.

86. Ivanna, interview, Kyiv, March 20, 2016.

87. Olena, interview, Kyiv, January 12, 2016.

88. This finding is consistent with Joshua Tucker's argument about the significance of corruption as a motivation for mass mobilization during electoral revolutions in the early 2000s. For details, see Joshua Tucker, "Enough! Electoral Fraud, Collective Action Problems, and Post-Communist Colored Revolutions," Perspectives on Politics 5, no. 3 (September 2007): 535-51.

89. On corruption during Yanukovych's presidency, see Anders Åslund, "Why Ukraine Is So Poor, and What Could Be Done to Make It Richer," Eurasian Geography and Economics 55, no. 3 (2014): 236-46; Serhiy Kudelia, “The House that Yanukovych Built," Journal of Democracy 25, no. 3 (July 2014): 19-34. 
in her hometown and later influenced her decision to become engaged in the EuroMaidan:

I come from a small town where corruption is rampant. I could not do anything there because everyone was so corrupt. If you stood up for your rights, someone would come and burn down your house, and the police would do nothing ... when [Mustafa] Naiiem posted a call to go to the Maidan, I responded. I helped out in any way I could. I felt a little bit like a member of the white guard [bilogvardiiets], except we were fighting for human rights, for the right to be treated as a human being by our government, rather than fighting for the tsar. ${ }^{90}$

Likewise, forty-year-old Kateryna from Bila Tserkva, a city fifty miles south of Kyiv, cited corruption as a motivation for her involvement in the protest campaign:

I joined the protests because I firsthand experienced the injustices of the regime and I've had enough of it. My business got raided as soon as it made a profit, it was a legal car wash. My house had bricks thrown at it when I tried to complain. I live in a small town where everyone knows everyone, and this sort of violence wasn't present even in the 90s. The police and government officials walked around as if they owned the place, and they were all members of the Party of Regions. If you weren’t [a party member], you were as good as dead..$^{91}$

As seen in Table 2, solidarity with protesters was another major reason for women's activism. Several middle-aged respondents reported that their spouse's participation in the protest campaign influenced their decision to join it. In contrast, younger respondents, including high school and university students, discussed the importance of peer influence. For example, sixteenyear-old Myroslava recalled how her classmates joined the EuroMaidan: "I was in high school at that time, and one day the entire class decided to go to the Maidan. And afterwards we stayed [there] because we felt that it was the right thing to do ... the idea of dignity permeated the air, and everybody tried to be their best, to be better than the scum in the government." 92

The notion of activist mothering provided a powerful motivation for protesting among women with firsthand child-rearing experience. Eighty percent of those who employed a "maternalist frame" to explain their protest behavior were mothers. ${ }^{93}$ Drawing on their social identities as mothers and grandmothers, the interviewed women expressed determination to protect their children and grandchildren against police violence and secure a better future for younger generations of Ukrainians. For example, Oksana,

90. Yaryna, Skype interview, January 13, 2016.

91. Kateryna, Skype interview, May 5, 2016.

92. Myroslava, Skype interview, January 25, 2016.

93. The "maternalist frame" denotes "elements of motherhood, mothering, and maternal identities deployed to evoke meanings within a given context and elicit participation and/or support of collective action," see Michelle Carreon and Valentine Moghadam, "Resistance Is Fertile": Revisiting Maternalist Frames across Cases of Women's Mobilization,” Women’s Studies International Forum 51 (July-August 2015): 19. 
twenty-four-year-old mother of two children, spoke about the so-called maternal instinct as a driving force behind women's civic engagement:
Many women, including myself, participated because they understood that we, as womankind, bear responsibility for our children and our husbands. Women understood that they could do things that are irreplaceable and nec- essary, even if men did not recognize it. There is a certain maternal instinct in all women, and I think women deeply understand their social role and public needs, and perform it even if they get nothing in return..$^{94}$

Consistent with Naples's argument, this study finds that female protesters broadened the traditional definition of mothering to encompass their voluntary work for the betterment of their community. Many women felt that they could not stand on the sidelines when both the future of their country and the well-being of their children were in jeopardy. Solomiia, a thirty-year-old mother of two children, stated: "I am interested in what will happen to my country, where my children will live. Ukraine is a country rich with resources and potential, and the old regime misused them and outright stole. They plundered our people and ravaged the country, and I want a better future for my family. I would like to see my country flourish. I would like my children to live in a civilized country and have a good life." 95

Also a mother, thirty-seven-year-old Olha expressed a similar mix of feelings: "I think that a lot of women, myself most definitely, felt a motherly feeling and duty towards the protesters and our country. We were there to take care of the movement, and in doing so, our country. While it seems to some people that we were merely cleaners and cooks, we were so much more than that. Women were the glue that made this movement last and succeed."96

Likewise, the interviewees invoked motherhood when they described their motivations for protesting in favor of the free trade agreement with the EU or against the use of excessive violence against peaceful protesters. This finding is consistent with women's behavior during the revolutionary situation. In February 2014, for example, a few dozen women, with self-made signs "Mother" pinned to their clothes, organized a march in front of the police cordon on the Maidan and addressed the government with a plea: "Do not to kill our children!" ${ }^{97}$ Women also blockaded military bases to disrupt the execution of orders regarding the violent dispersal of protesters. ${ }^{98}$ Outrage over police violence against university students in November 2013 motivated Uliana, a retired university professor, to join the protests: "I was outraged over the things that happened to the kids. Usually I stay out of things, but I just couldn't bear it any longer. We, all the professors, went together [to the Maidan] because

94. Oksana, Skype interview, March 1, 2015.

95. Solomiia, Skype interview, March 1, 2015.

96. Olha, interview, Kyiv, March 19, 2015.

97. Radio Svoboda, “Materi zaklykaly sylovykiv 'ne vbyvaty ditei,'” February 1, 2014, at https://www.radiosvoboda.org/a/25250147.html (last accessed January 25, 2017).

98. Mariana Petsukh, "Sabotuvaty ne mozhna vykonuvaty," Ukrainska Pravda January 26, 2014, at http://www.pravda.com.ua/articles/2014/01/26/7011309/ (last accessed January 25, 2017). 
our students were there, and it was time we united with them. We hoped that the more people were there, the safer the kids would be." ${ }^{99}$

Interest in gauging the authenticity of the anti-government protests provided another incentive for some women's arrival at the protest site. Forty-four-year-old Zlata, for example, admitted that her professional experience-employment at an international organization-had piqued her interest in the EuroMaidan: "Everyone was going crazy over the Maidan at the time so I went to see for myself what was really going on. I also had a professional interest because I worked with public opinion polls and stuff like that. The question that interested me most was whether the Maidan was a genuine grassroots phenomenon or a carefully orchestrated PR campaign. I wanted to see with my own eyes how it was organized."100

The provision of much needed professional services was cited as another reason for women's engagement in the protest campaign. Trained as a nurse, forty-year-old Iryna was moved by a mix of civic and professional duties: "This protest was my duty as a Ukrainian. Plus, I have a medical background so I could be useful," she said. ${ }^{101}$ A few interviewees were mobilized via their professional associations. The Ukrainian Association of Psychologists, for example, brought a large number of its members to the encampment to provide counseling for protesters, especially during an escalation in police violence. ${ }^{102}$ Khrystyna, twenty-five-year-old graduate student in psychology, described how she had been touched by the amount of human suffering on the Maidan:

My decision was primarily driven by the desire to alleviate human suffer-
ing, of which there was plenty. I was also very concerned about the effects
of these events on the human psyche and therefore society at large. There
was a lot of anxiety among people. Fear for themselves, their families, fear
of getting hurt or killed. But there was also fear for the country, concern over
its future, anxiety about the economic situation, and of course there was also
the fear of "what if we do not win?". . . there were also many great women
who were truly fearless, who fought with men despite sexual harassment
and police threats. ${ }^{103}$

Turning to women's issues, only three out of thirty-seven respondents explicitly mentioned women's empowerment as a primary motivation for their involvement in the EuroMaidan. Having been a women's rights advocate for several years, thirty-five-year-old Olesia joined a women's squad to champion the idea of gender equality and boost the visibility of women in the protest campaign. Olesia explained: "It was an opportunity for real societal change, and as a women's rights activist I could not leave the gender question out of

99. Uliana, interview, Kyiv, March 16, 2015.

100. Zlata, interview, Kyiv, March 17, 2015.

101. Iryna, Skype interview, January 20, 2016.

102. For a detailed discussion of health care provision during the EuroMaidan, see Anna Kvit and Tetiana Stepurko, "Medical Care on the Euromaidan: Who Have Saved the Lives of the Protesters?" Social, Health, and Communication Studies Journal 1, no. 1 (November 2014): 80-104, at https://journals.macewan.ca/shcsjournal/article/view/253 (last accessed June 20, 2018).

103. Khrystyna, interview, Kyiv, March 15, 2015. 
the creation of a new political order ... when men are the only people defending the protests, it gives them the right to claim any victory as theirs, and there is no place for that in contemporary Ukraine."104

Similarly, twenty-five-year-old Maria underscored the significance of women's engagement in the EuroMaidan for the betterment of women's position in Ukrainian society: "I was a member of a feminist organization, and I joined [the EuroMaidan] when we realized that it was more than a protest against the cancellation of a trade deal, it was a fight for human rights. It was important for women to participate because since the French Revolution, there is a tradition of excluding women from all the decision making and reforms, because we supposedly don't give our blood and sweat to the movement.".105

An abundance of anecdotal evidence demonstrates women's encounter with sexism on the Maidan. ${ }^{106}$ A placard inside the encampment diminished women's role in the protest campaign, stating: "Woman, if you see a mess, clean it up; it will please a [male] revolutionary." Furthermore, given a surge in police violence in January 2014, Maidan commandant Andrii Parubii advised women against participating in direct combat on the barricades. As noted by a woman protester, "the traditional model of interactions between men and women in society, their unequal access to resources, was unfortunately reproduced in the course of revolutionary events." ${ }^{107}$ In response, feminist activists organized the Night of Women's Solidarity on the Maidan and started a Facebook group "Half of Maidan: Women's Voice of Protest" (Polovyna Maidanu: Zhinochyi golos protestu). ${ }^{108}$ One of their initiatives dealt with a design of posters portraying women's heroism on the Maidan. ${ }^{109}$ Moreover, some women began to form women's self-defense units and offer

104. Olesia, interview, Kyiv, March 15, 2015.

105. Maria, Skype interview, March 1, 2016.

106. Anna Gritsenko, "Kak Evromaidan otpravlial zhenshchin na kukhniu"; Halyna Herasym, "Evromaidan: Chy kukhnia dosi iedyne mistse dlia ukrainskikh zhinok?”; Olesya Khromeychuk, “Gender i natsionalism na Maidani," October 27, 2015, at http://www. historians.in.ua/index.php/en/dyskusiya/1673-olesia-khromeichuk-gender-i-natsionalizm-na-maidani-a; Maria Mayerchyk and Olga Plakhotnik, "Ukrainian Feminism at the Crossroad of National, Postcolonial, and (Post)Soviet: Theorizing the Maidan Events 2013-2014," Krytyka (November 2015), at https://krytyka.com/en/community/blogs/ ukrainian-feminism-crossroad-national-postcolonial-and-postsoviet-theorizing-maidan; Daria Popova, "Seksizm na Maidani;" Iryna Virtosu, "Ne buterbrodom iedynym, abo navishcho Maidanu Zhinocha sotnia," Ukrainska Pravda, February 4, 2014, at http://life. pravda.com.ua/society/2014/02/5/151445/ (last accessed January 30, 2017).

107. Anonymous, "Kusochek Maidana v Kharkove," Gendernyi zhurnal "Ia” 35 (2014), 20, at http://krona.org.ua/assets/files/journal/Gendernyi-zhurnal-Ya-35-2014.pdf (last accessed June 16, 2018).

108. Tetiana Bureichak and Olena Petrenko, “Kanapki, Sich ta 'banderivki,"” Zaxid. net, January 8, 2014, at https://zaxid.net/kanapki_sich_ta_banderivki_n1300428; Den, "V nich na zavtra vidbudetsia Nich zhinochoi solidarnosti," December 12, 2013, at http:// day.kyiv.ua/uk/news/121213-vnich-na-zavtra-vidbudetsya-nich-zhinochoyi-solidarnosti; Anastasiia Moskvychova, "Zhinky na Maidani: Abo kuhnia, abo barykady?” Radio Svoboda, February 4, 2014, at https://www.radiosvoboda.org/a/25252319.html (last accessed July 31, 2017).

109. For a sample of posters, visit Volyn Post, “Zhinky na Maidani. Foto,” December 12, 2013, at http://www.volynpost.com/news/24320-zhinky-na-ievromajdani-foto (last accessed January, 30 2017). 
master classes in self-defense. ${ }^{110}$ Nina Potarska, a sotnia's co-founder, considered the women's squad "a resource for amplifying the 'woman's voice' under conditions of egregious discrimination." 111 By the same token, women's initiatives challenged the traditional definition of women's role as Berehynia by making women more visible in a male-dominated public space.

Furthermore, faced with men's gender stereotypes inside the encampment and biased media coverage of the revolutionary situation, some women who did not consider women's rights as a pivotal issue at the start of the antigovernment protests began to challenge a gender-based division of labor on the Maidan and construct an alternative narrative of women's engagement in the EuroMaidan. Twenty-one-year-old Nadiia recalled how she fought against gender discrimination inside the encampment:
My future and the future of my generation were on the line. My husband was also very much into it. And I felt the need to support him. At first I went because he was there. But he hung out with other men. Men made barricades and other defensive structures. I joined a lot of women who were discuss- ing politics. We had our discussions in the kitchens ... when there were wounded, I went on runs to get medical supplies, and my friends and I fought hard for the right not to be sent home. The men tried to tell us that it was not our place, but at that time I believed that it was as much my responsibility to defend my rights as it was my husband's. ${ }^{112}$

A limitation of these findings is that they cannot be generalized to the whole population of female protesters. Nonetheless, the findings presented in this article are consistent with the results of the Ukrainian Protest Participant Survey $(\mathrm{n}=1475)$ conducted between November 26, 2013 and January 10, 2014. ${ }^{113}$ Olga Onuch and Tamara Martsenyuk found that both male and female survey respondents mentioned concerns about the quality of life and human rights abuses as top reasons for protesting, while women were slightly more motivated by police violence against students than men. ${ }^{114}$ Additional data from Onuch and Martsenyuk's rapid on-site interviews show that parenthood was more frequently cited by women than men as an incentive for protest behavior. Similarly, women polled by the DIF, in collaboration with the KIIS, on December 7-8, 2013, mentioned outrage over police violence against peaceful protesters (70.9 percent), disapproval of the president's refusal to sign a free trade agreement (53.3 percent), and the desire to improve the quality of

110. Olha Vesnianka, "Interview with Nadia Parfan: 'Vitaiu Zhinochu sotniu," February 1, 2014, Gender Museum Archive, at http://gender.at.ua/load/2-1-0-206; Zerkalo nedeli, "Na Maidane sozdali zhenskii otriad samooborony" February 4, 2014, at https://old. zn.ua/UKRAINE/na-maydane-sozdali-zhenskiy-otryad-samooborony-138083_html (last accessed July 31, 2017).

111. Nina Potarska, “Zhinocha sotnia na Maidani,” Gendernyi zhurnal "Ia” 35 (2014): 18, at http://krona.org.ua/assets/files/journal/Gendernyi-zhurnal-Ya-35-2014.pdf (last accessed June 16, 2018).

112. Nadiia, interview, Kyiv, December 20, 2015.

113. For details, visit the web page of the Ukrainian Protest Project, https://ukrainianprotestproject.com/data-and-data-collection (last accessed February 1, 2017).

114. Olga Onuch and Tamara Martsenyuk, "Mothers and Daughters of the Maidan,” 114. 
life in Ukraine (53.3 percent) as their main reasons for protesting. ${ }^{115}$ The findings support the argument that political discontent, along with the notion of activist mothering, provided a rationale for women's protest behavior.

This study has examined why women in post-communist Ukraine joined a protest campaign. Taken together, the findings reveal a broad spectrum of motivations for women's involvement in the EuroMaidan, ranging from dissatisfaction with the government and civic duty to solidarity with protesters and professional service. These findings have important implications for the study of contentious politics in eastern Europe. A great deal of empirical work has focused on motherhood as an incentive for women's political engagement. Consistent with prior research, this study demonstrates that a broadened understanding of mothering can serve as a catalyst for women's activism in a repressive political regime. Women's concerns about the well-being of their biological children can evolve into a broader concern about the future of their country, which might spur women to action despite the high costs of activism. This study, however, finds that the notion of activist mothering is mostly salient among women with child-rearing experience. Apparently, a wide range of factors influences women's propensity to protest. Further research needs to explore how different social identities intersect and reinforce women's engagement in contentious politics in non-democracies.

The EuroMaidan's impact on the status of women in Ukrainian society is another avenue for future research. The Cabinet of Ministers of Ukraine adopted a state program on gender equality in December 2006. ${ }^{116} \mathrm{~A}$ followup program was adopted in September 2013. ${ }^{117}$ The incumbent government, however, failed to make significant progress in implementing democratic reforms and enforcing gender mainstreaming policies. With the appointment of Volodymyr Groisman as Prime Minister in April 2016, women were nominated to head only two Ministries: the Ministry of Education and Science and the Ministry of Health. ${ }^{118}$ This distribution of minister portfolios appears to reinforce a gender-based segregation in the labor market and the exclusion of women from key positions of power.

Moreover, women's activism in response to Russia's annexation of Crimea and the violent conflict in eastern Ukraine is a fruitful area for future research. Numerous reports indicate that the conflict has engendered the growth of civil society and in particular the development of a volunteer movement. ${ }^{119}$

115. Author's own calculations, using DIF/KIIS survey data.

116. Cabinet of Ministers of Ukraine, Postanova vid 27 grudnia 2006 r. N 1834 "Pro zatverdzhennia Derzhavnoi programy z utverdzhennia gendernoi rivnosti v ukrainskomu suspilstvi na period do 2010 roku," at http://zakon4.rada.gov.ua/laws/show/1834-2006\%D0\%BF (last accessed August 28, 2016).

117. Cabinet of Ministers of Ukraine, Postanova vid 26 veresnia 2013 r. N 717 "Pro zatverdzhennia Derzhavnoi programy zabespechennia rivnykh prav ta mozhlyvostei zhinok i cholovikiv na period do 2016 roku," at http://zakon2.rada.gov.ua/laws/show/717-2013\%D0\%BF/ (last accessed August 28, 2016).

118. For a full list of the Cabinet of Ministers, see https://www.kmu.gov.ua/ua/team (last accessed May 3, 2018).

119. See, for example, Olga Boichak, "Battlefront Volunteers: Mapping and Deconstructing Civilian Resilience Networks in Ukraine," Proceedings of the 8th International 
Since Ukraine faced an unprecedented refugee crisis, with more than 1.5 million internally displaced people (IDPs), civic activists stepped in to provide assistance for IDPs and compensate for the inefficiency and corruption inside government agencies. In addition, women organized fundraising campaigns to supply the cash-strapped army with food, clothes, and medical equipment. Future work should explore multifaceted forms of women's activism in conflict-ridden societies and identify conditions under which women can achieve greater gender equality.

Conference on Social Media and Society, Toronto, Canada, July 2017, at https://dl.acm. org/citation.cfm?id=3097289; Irene Fellin, "The Role of Women and Gender Policies in Addressing the Military Conflict in Ukraine" (Istituto affari internazionali, Rome, Italy, 2015), at http://www.iai.it/en/pubblicazioni/role-women-and-gender-policies-addressing-military-conflict-ukraine; Volodymyr Malynka and Olha German, "Volontery viiny," Dzerkalo tyzhnia July 18 (2014), at https://dt.ua/socium/volonteri-viyni-_.html (last accessed November 20, 2017). 